\title{
Earthshipak: Bideragarriak al dira hornidura-sarearekiko konexiorik behar ez duten etxebizitza ekologikoak Euskal Autonomia Erkidegoan?
}

\author{
Enara Zarrabeitia Bilbao*, Izaskun Alvarez Meaza \\ Enpresen Antolakuntza Saila. Bilboko Goi Ingeniaritza Eskola Teknikoa. \\ Euskal Herriko Unibertsitatea (UPV/EHU) \\ *enara.zarrabeitia@ehu.eus
}

DOI: 10.1387/ekaia.13182

Jasoa: 2014-11-14

Onartua: 2015-04-20

Laburpena: Earthshipek eraikuntza konbentzionalaren eredua erabat eraldatu dute. Azken urteotan, hain zuzen, bioeraikuntzaren oinarriak aplikatuz hainbat etxebizitza mota eraiki dira, baina haien artean earthshipak izan dira etxebizitza konbentzionalekiko haustura nabarmenena ekarri dutenak. Hala, gaur egun praktikan dagoen eraikuntza-ereduak eraldaketa bat igaro behar duela esateak ez digu ekarpen berririk egiten, jakina baita, eredu horrek ez duela helburu gisa jendartearen eta ingurumenaren oreka. Gure ingurua etengabe urratzen duen eraikuntza-ereduak muga jo du edo joko du. Kontu horri erreparatzen dio, hain zuzen, earthship filosofiak: inguruaren eta gizakien arteko oreka erabatekoa helburu modura duen eraikuntza-eredua. Lehenengo earthshipa Taosen (Mexiko Berrian) eraiki zen orain dela berrogei bat urte, eta gaur egun, mundu osoan zehar 3.000 baino gehiago daude, baina Euskal Autonomia Erkidegoan guztiz ezezaguna da eraikuntza mota hori. Horregatik, ikerlan honetan aztertuko da earthshipak zer diren, berauen oinarriak zein diren, eta Euskal Autonomia Erkidegoan ere bideragarriak ote diren.

Hitz-gakoak: Earthship, etxebizitza ekologikoak, energia-kontsumo baxuko eraikinak, Euskal Autonomia Erkidegoa.

\begin{abstract}
Earthships have totally changed the model of conventional construction. In the last years, various types of houses have been built using different principles of green building, but among them the earthships are those that have the greatest break with conventional houses. In this way, to say that the model of construction that is in practice at present must change does not say anything new to us, since it is known that it does not look for the balance between the environment and the persons. The current model of construction that continuously harms our environment has reached or will reach its limit. The earthship philosophy focuses on this context: the building model
\end{abstract}


that seeks a balance between the environment and people. Although the first earthship was built over forty years ago in Taos (New Mexico), and there are now over 3,000 worldwide, in the Basque Autonomous Community this type of construction is completely unknown. Therefore, what are the earthships, what are their principles, and if they are also viable in the Basque Autonomous Community are discussed in this research.

Keywords: Earthship, ecological houses, nearly zero energy buildings, Basque Autonomous Community.

\section{SARRERA}

Adituek diotenaren arabera, mende amaierarako giro-tenperaturaren igotzea lautik sei Celsius gradurainokoa izango da, eta klima-aldaketaren ondorioz, maiztasun handiagoz gertatuko diren ekaitzak gero eta bortitzagoak izango dira $[1,2]$. Klima-aldaketa saihesteko ez da hartu, oraingoz, mundu-mailako neurri orokor eta benetan eraginkorrik. Aitzitik, badira tokian tokiko neurriak, edo maila indibidualetik abian jarri diren ekimenak, ekimen horien sorburuko filosofia ahalik eta gehien orokortzeko asmoarekin. Testuinguru horretan, azken urteotan hedatzen ari den ekimen-arloetako bat da energiaren aldetik eraginkorragoak diren eta naturarekiko samurragoak diren eraikinak egitea.

Espainiar estatuan, eraikuntzaren esparruak energiaren \% 40 eta ingurumen-baliabideen \% 40a kontsumitzen du. Gainera, oso handia da energia-menpekotasuna; izan ere, kontsumitzen den energiaren \% 85 inportatu egiten da [3].

Gauzak horrela, gaur egun eraikuntzak ingurumenarekiko duen inpaktu ekologikoa murrizteko joera dago, eta horretan, aitzindaria izan da bioeraikuntza. Espainiar estatuan, joan den mendeko 80 eta 90eko hamarkadetan, gehienez \% 60ko energia-aurreztearekin eraikitzen zen bitartean, bioeraikuntzako proiektuek energia-eraginkortasunaren kontzeptua jasotzen zuten dagoeneko, eta \% 95eko aurreztea aurreikusten zuten [4]. Hala ere, gizarteak, oro har, gero eta kontzientziazio maila handiago du eraikuntza jasangarriaren inguruan, eta duela urte batzuk bai Europak (2002/91/ EC zuzentaraua eta 2010/31/EU zuzentaraua), bai espainiar estatuak (253 /2013 Errege Dekretua) argitara eraman zuten eraikinen energia-eraginkortasunaren inguruko araudia $[5,6,7]$. Hala eta guzti, oraindik ere egiteko bide luzea dago arlo horretan. Espainiar estatua oso motel betetzen ari da araudia, eta Europar Batasuneko auzitegiak kondenatua ere izan da eraikinen energia-eraginkortasunaren inguruko zuzentaraua ez betetzearren (C-67/12 gaian Europar Batasuneko auzitegiak Espainia kondenatzen du 2002/91/EC zuzentarauaren 3, 7 eta 8 artikuluak betetzeko beharrezkoak diren neurriak ez hartu izanagatik) [8]. 
Earthshipak: Bideragarriak al dira hornidura-sarearekiko konexiorik behar ez duten etxebizitza ekologikoak Euskal Autonomia Erkidegoan?

Dena den, urriak izan dira erakunde publikoek eraikinen energia-eraginkortasunaren eremuan emandako urratsak baina badaude harago joan diren ekimen eta proiektuak. Hainbatek probatu du posible dela hornidura-sareetara (sare elektrikora, ur-sarera, edo saneamendu-sarera) konektatzea behar ez duten etxebizitza ekologikoak eraikitzea; hau da, frogatu dute earthshipak posible direla. Baina, zertan desberdintzen dira earthshipak gainerako etxebizitzetatik? Zer dira, bada, earthshipak? Zein dira eartshipen oinarriak? Bideragarriak ote dira earthshipak Euskal Autonomia Erkidegoan?

\section{ETXEBIZITZA KONBENTZIONALAK, ENERGIA-KONTSUMO BAXUKO ETXEBIZITZAK ETA EARTHSHIPAK}

Ezin esan daiteke etxe kontzeptuaren esanahia asko aldatu denik mendeetan zehar. Hasiera batean, etxe edo etxebizitzak kanpo elementuetatik babesteko konpartimentuak ziren. Denbora laburrera, argiztapena, sua, ura eta arrazoizko erosotasun-maila eskatzen zuten gauzak egiten hasi ziren konpartimentu horietan. Hori lortu ahal izateko, konpartimentu horietara energia eta ura eramaten hasi ziren, eskuz lehendabizi, sistemen bidez geroago. Sistema horiek zeharo aldatu dira urteetan zehar, su-hobietara egurra garraiatzetik energia kantitate handia sortzen duten zentral nuklearretaraino. Dena den, sistemen aldaketa erabatekoa izan den arren, konpartimentuak konpartimentu izaten jarraitzen du $[9,10,11]$.

Hain zuzen ere, hornikuntza-sistema horietan datza earthship eta gainerako etxebizitzen arteko desberdintasun nagusia. Hala ere, badago bestelako desberdintasunik, besteak beste, konpartimentu horiek lortzeko erabiltzen diren eraikuntza-tekniketan eta materialetan.

Egun, gure inguruan ohikoenak diren etxebizitza edo eraikinak konbentzionalak edo estandarrak dira. Eraikin horiek dira, legearen araberako energia-eskakizun minimoak betez, herrialdeko ohiko eraikitze-praktikei jarraituz eraikitzen direnak $[12,13]$.

Eraikuntza konbentzionalean diseinu jasangarriko oinarriak ezarri nahi badira, ingurumenarekiko jasangarriak diren eraikuntza-materialak erabiltzea da modurik errazena. Material naturalek (egur naturala, harea, legarra eta abar) gizakiak eraldatutako materialek baino energia erantsi ${ }^{1}$ gutxiago

1 Eraikinen bizi-zikloan bi energia mota beharrizan desberdintzen dira [7, 9].

- Energia erantsia: Ondasun eta zerbitzuen fabrikaziorako behar den energia, besteak beste, eraikuntza-materialentzako.

- Funtzionamendu-energia: Fase operatiboan eraikinetan erabilitako energia, besteak beste, berokuntza, hozte, aireztapen, ur bero, argiztapen eta beste aparailu elektriko batzuentzako. 
eta toxikotasun txikiagoa daukate [14], eta ondorioz, ingurumen-inpaktu txikiagoa. Alabaina, eraldatutakoak dira gaur egun gehien erabiltzen diren materialak; izan ere, etxebizitza konbentzionaletan ohikoenak diren materialak dira tratatutako egurra, hormigoia, adreiluak, teilak, beira-zuntza eta plastikoa [15].

Etxebizitza konbentzionalez gain, badaude energia-kontsumo baxuko etxebizitzak ere. Nahiz eta etxebizitza horietarako definizio orokorrik ez dagoen [16], etxebizitza hauek diseinu-irizpide bereziei jarraiki eraikitzen dira eraikinaren funtzionamendu-energia ${ }^{1}$ minimizatzeko asmoz $[12,13]$.

Europako zuzentarau baten arabera (2010/31/EU), 2020ko abenduaren 31rako eraikin berri guztiak energia-kontsumo ia nuluko eraikinak izan beharko dira, Nearly Zero Energy Buildings deritzonak (aurrerantzean, NZEB). Gainera, estimulu-politikak sustatu beharko dira dagoeneko eginda dauden eraikinak NZEB eraikinetara eraldatzeko.

Eraikin horiek energia kantitate txikia behar dute, eta energia-eraginkortasun oso altuko eraikinak dira. Hala, hein handi batean, energia berriztagarriz hornituko dira, besteak beste in situ edo inguruan sortutako iturri berriztagarriez [6].

Espainiar estatuaren kasuan, 235/2013 errege-dekretuak jasotzen ditu Europako zuzentarauaren araberako betebeharrak NZEB arloan. Bertan ezartzen dira, alde batetik, zein diren bete beharreko muga-datak; beste alde batetik, ezartzen da Eraikuntzaren Kode Teknikoak jasoko dituela NZEB eraikinek bete beharko dituzten baldintzak [7,17]. 2020 urtera arte urte batzuk falta dira oraindik baina hainbat dira arlo horretan Espainiar estatuak eman beharreko urratsak, Europako legeria bete nahi badu [18].

Bestalde, funtzionamendu-energia minimizatu nahi dute energia-kontsumo baxuko etxebizitzetan, baina hala ere nahiko antzekoak izaten dira etxebizitza horietan erabiltzen diren materialak eta etxebizitza konbentzionaletan erabiltzen diren materialak. Are gehiago, energia-kontsumo baxuko etxebizitzek, energia erantsi gehiago daukate besteak beste, isolamendubolumen handiagoak behar dituztelako $[13,15]$.

Guztira, energia-eraginkortasunaren arloko beharren ondorioz, aldatu egin beharko da egungo etxebizitza-eraikuntzaren eredua. Etxebizitzen funtzionamendu-energia eta energia erantsia murriztu nahiak berrikuntzaepealdia ekarriko du eraikuntzara. Alegia, energia aurreztuko bada, prozesu, material eta teknologia berrietan inbertitu beharko da.

Aitzitik, batzuk badaude lanean orain dela berrogei urte baino gehiago energiaren ikuspegitik guztiz eraginkorrak eta ekologikoak diren eraikuntzetan. Industriako teknokraziaren disidentetzat har daitekeen Michael Reynolds arkitektoak eraiki zuen, material naturalekin eta hondakinak berrerabiliz, hornidura sareekiko konexiorik behar ez duen lehen etxebizitza 
Earthshipak: Bideragarriak al dira hornidura-sarearekiko konexiorik behar ez duten etxebizitza ekologikoak Euskal Autonomia Erkidegoan?

1972. urtean, hau da, lehen earthshipa eraiki zuen. Eraikin horiek arkitektura alternatiboaren prototipoak dira, eta ingurumen-efizientzia eta permakultura aplikatuaren adibide garbia.

\section{EARTHSHIPAREN NONDIK NORAKOAK}

Earthshipak material birziklatuz eta, neurri handi batean, material naturalez eraikitako etxebizitza ekologiko eta autonomoak dira (ikusi 1. irudia). Eraikin horiek ez dira hornidura-sareekin konektatzen; modu pasiboan berotzen eta hozten dira; behar duten elektrizitatea sortzen dute eta behar duten ura batzen dute; bestetik, hondakin-urak tratatzen dituzte eta janaria ekoizten dute [19].

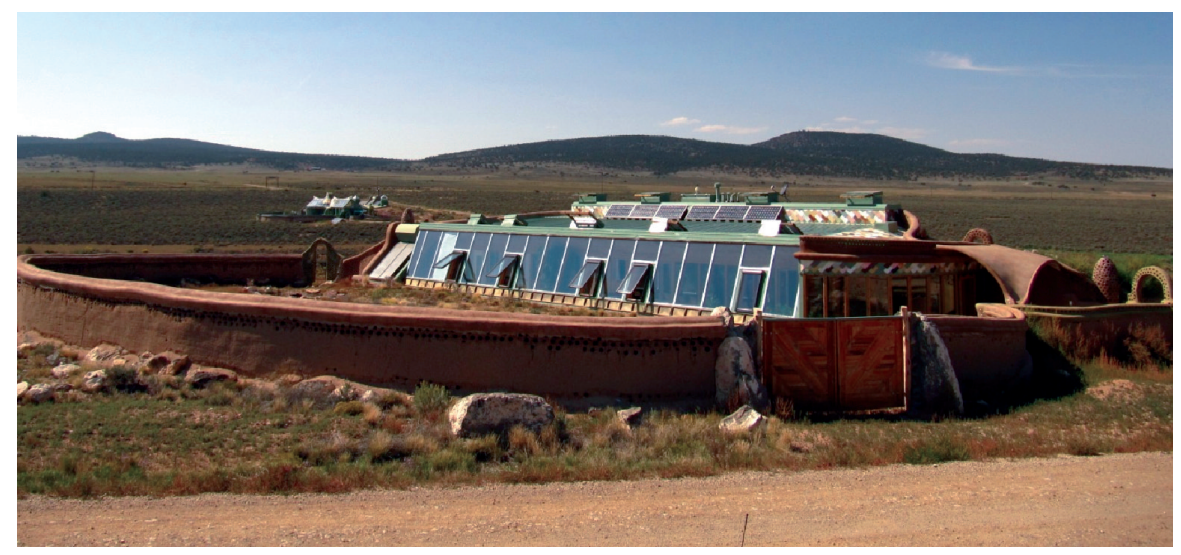

1. irudia. Mexiko Berrian kokatutako earthship bat [19].

Kontzeptualki bakunak dira, baina badituzte hainbat berezitasun. Hortaz, ondorengo lerroetan sakonago aztertuko da earthshipen kontzeptua. Horretarako, biotekturan oinarritutako eraikin horien hastapenak eta bilakaera aztertuko dira; eraikuntzarako erabilitako materialak zein diren ikusiko da, eta bai zein hornidura-sistema mota erabiltzen duten. Azkenik, zenbait eraikin-modelo aurkeztuko dira.

\subsection{Earthshiparen hastapenak eta bilakaera}

Joan den mendeko hirurogeiko hamarkadaren bukaeran, Cincinnatiko Unibertsitatean arkitektura-ikasketak bukatu bezain laster, Michael Reynoldsek (1945) (ikusi 2. irudia) arkitektura konbentzionala alde batera utzi eta Taoseko konderrira joan zen (Mexiko Berria), ingurumenari hainbeste 


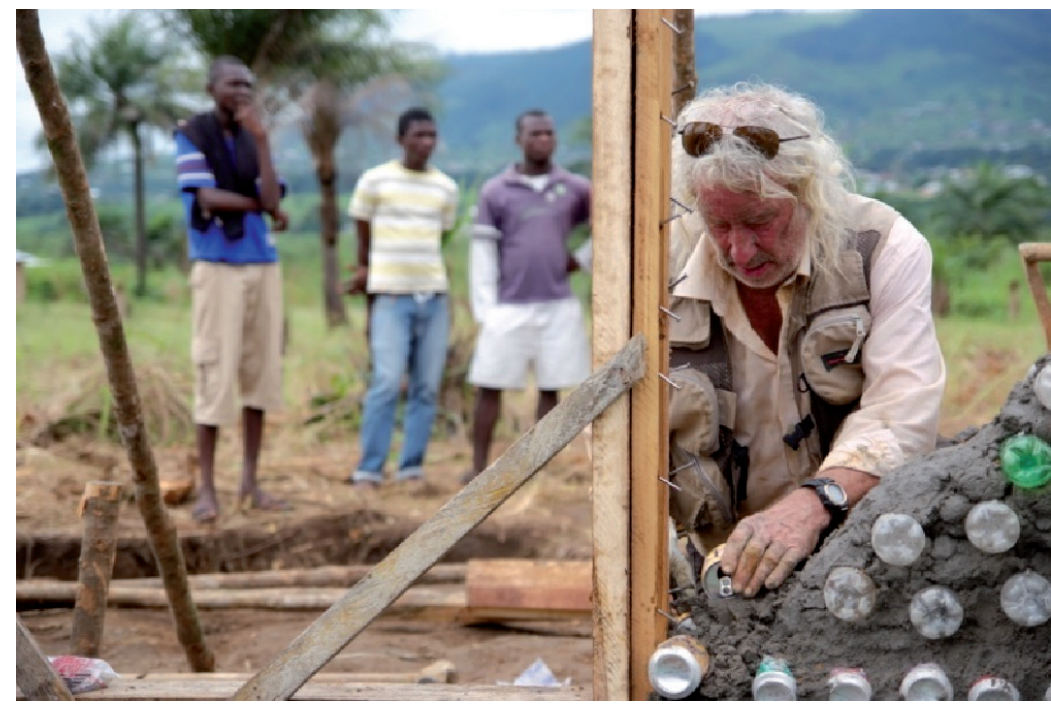

2. irudia. Michael Reynolds arkitektoa [argazkiaren egilea: Robert Eke].

erasotzen ez dion den arkitekturan lan egiteko. Eraikuntza-araurik gabeko lurralde modura ezagutzen zen Taos. Bertan, Earthship Biotecture izeneko konpainia sortu zuen, eta material birziklatu eta diseinu berriekin esperimentatuz, garatzen hasi zen gaur egun mundu osoan zehar zabaldurik dauden eartship eraikin autonomoen kontzeptua.

Taoseko konderria klimatologia bortitzeko lurraldea da. Urteko prezipitazioak $300 \mathrm{~mm}$ inguru dira batez beste (Euskal Autonomia Erkidegoan, $1.729 \mathrm{~mm}$-ko batez besteko prezipitazioak izan ziren 2013. urtean); tenperatura $-34{ }^{\circ} \mathrm{C}$ eta $38{ }^{\circ} \mathrm{C}$ bitartekoa da han (Euskal Autonomia Erkidegoan, 2013. urtean tenperatura maximoa $41,6^{\circ} \mathrm{C}$-koa izan zen eta minimoa $-7,6^{\circ} \mathrm{C}$-koa) $[20,21]$. Muturreko klimatologia hori izanik, azken lau hamarkadetan, eraikin mota horietan esperimentatu da, eta etengabe egin da lan, eraikin horien diseinu eta errendimenduak hobetzeko. Taosen, egun, $2.700 \mathrm{~km}^{2}$-ko azalerako earthship komunitate bat dago, eta aurreikusitako 120 etxebizitzetatik erdia eraiki da [22].

Gainera, 3.000 earthship baino gehiago eraiki dira mundu osoan zehar klima desberdinetan egokitzea lortu ondoren, eta presio komertzial eta erregulatorioei aurre egin ondoren [1]. Gehienak Estatu Batuetan daude, baina Europan ere hainbat eraiki dira, eta eraikitzen ari dira (ikusi 3. irudia). 
Earthshipak: Bideragarriak al dira hornidura-sarearekiko konexiorik behar ez duten etxebizitza ekologikoak Euskal Autonomia Erkidegoan?
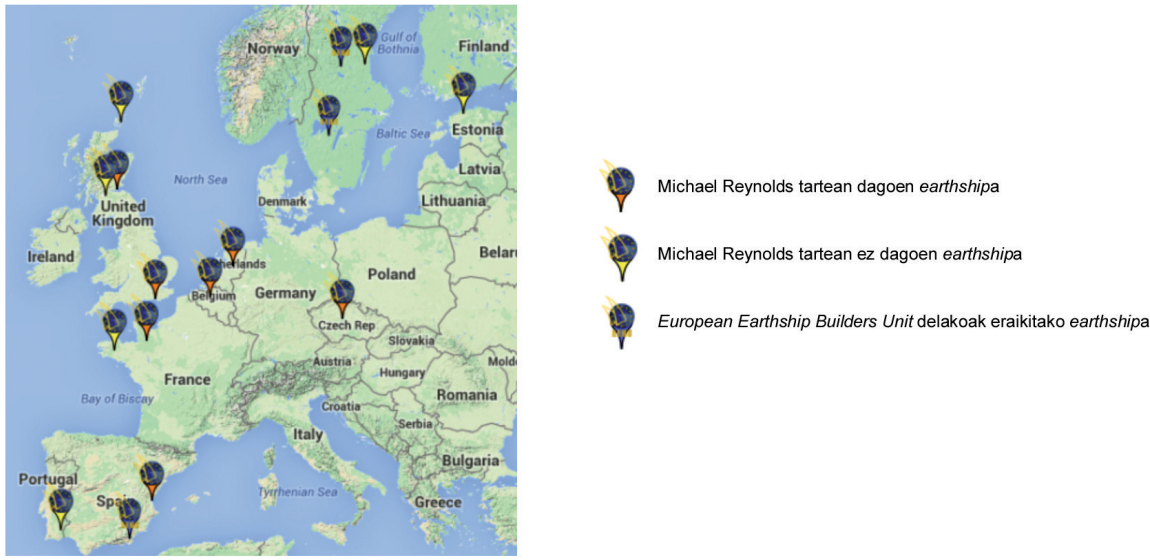

3. irudia. Europan eraiki diren eta eraikitzen ari diren earthshipak [23].

\subsection{Earthshiparen oinarriak}

Ondorengo lerroetan biotekturan oinarritutako earthship eraikinen funtsezko oinarriak azalduko dira.

\subsubsection{Earthshipak eraikitzeko erabilitako materialak}

Funtsezko material gisa erabiltzen dira material birziklatuak (pneumatikoak, aluminiozko freskagarri-latak eta kristalezko edo plastikozko botilak) eta material naturalak (adibidez, lurra).

Isolatzaile-eginkizuna izango duten horma nagusiak edo egiturazko hormak lortzeko, pneumatikoak erabiltzen dira (ikusi 4. irudia), adreilu

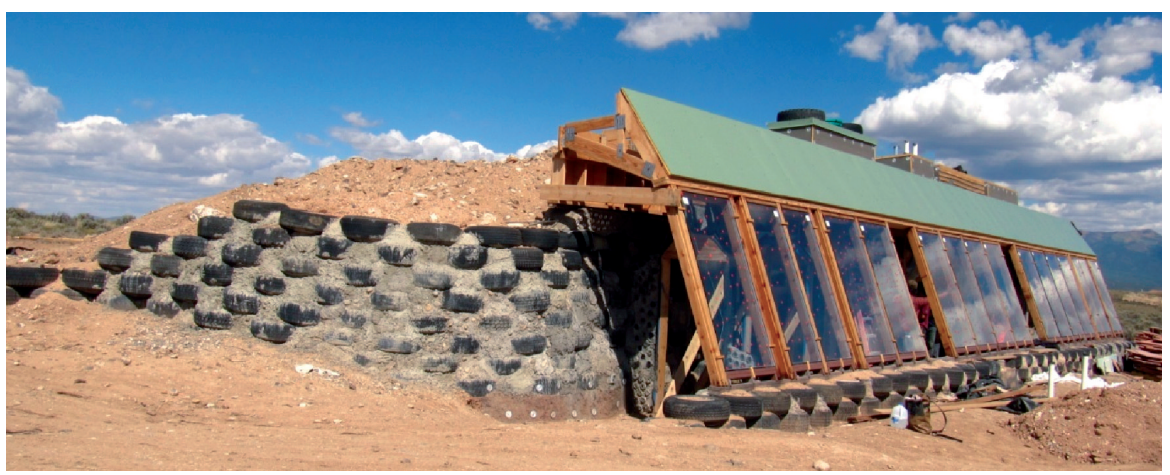

4. irudia. Birziklatutako pneumatikoz egindako earthship baten horma nagusiak [19]. 
gisa jarrita eta lur trinkoz beterik. Kasuan kasu, etxebizitzaren tamaina eta diseinuaren arabera, 500-5.000 pneumatiko behar izaten dira. Bestalde, horrela egindako hormek $90 \mathrm{~cm}$-ko lodierako masa izango dute, eta barnealdeko tenperatura konstante mantentzeaz gain, ia suntsiezinak izango dira $[19,24]$. Gainera, azpimarratzekoa da Wisconsin-Madisoneko Unibertsitatean eginiko ikerketa baten arabera, pneumatikoak zabortegietan arriskutsuak eta kutsagarriak izan daitezkeen arren, earthshipetan ez dutela inolako arriskurik sortzen [25].

Bestalde, aluminiozko lata eta botilak erabiltzen dira, batetik horma nagusien tarteak betetzeko, eta bestetik-barruko hormak edo egiturazkoak ez diren hormak eraikitzeko. Zementua eta egurra neurrigabe erabili barik, aluminiozko lata eta botila horiekin, hormigoiari forma ematen zaio modu errazean, eta barruko hormak edo egiturazkoak ez diren horma sendoak lortzen dira gainera $[19,24]$.

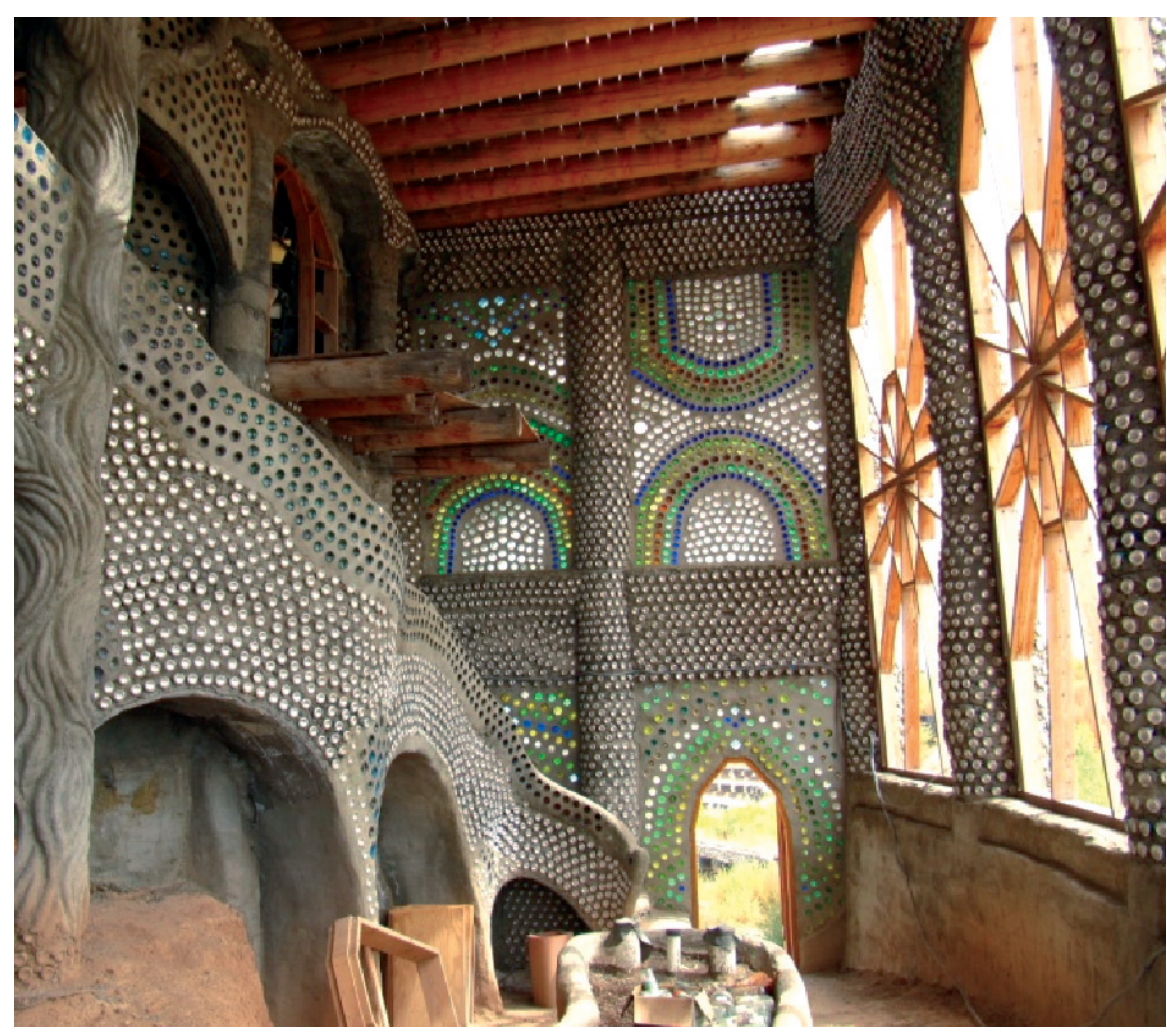

5. irudia. Birziklatutako lata eta botilak earthshipen hormetan [19]. 
Earthshipak: Bideragarriak al dira hornidura-sarearekiko konexiorik behar ez duten etxebizitza ekologikoak Euskal Autonomia Erkidegoan?

\subsubsection{Earthshipen funtzionamendurako beharrezkoak diren sistemak}

Ondorengo lerroetan ikusiko den bezala, earthshipek inguruari eragiten dioten moduagatik, berez lortzen dute egungo etxebizitzek eskatzen duten erosotasun maila $[19,24]$.

\section{Berotze- eta hozte-sistema}

Earthshipak era pasiboan berotu eta hozten dira. Horretarako, alde batetik, lurraren berezko tenperaturak eraikinaren tenperatura egonkortzen laguntzen $\mathrm{du}$; beste alde batetik, ezponda edo malda baten hondeaketan kokatuko diren pneumatikoez eraikitako earthshiparen hiru horma nagusiek (ipar hemisferioan, iparraldeko, ekialdeko eta mendebaldeko hormek), inertzia termiko handia sortuko dute. Horrela, eguzki-izpiek egunean zehar masa termikoa berotzen dute; gauean aldiz, hormek tenperatura banatzen dute, earthshiparen tenperatura hormetako tenperatura baino baxuagoa denean (ikusi 6. irudia).
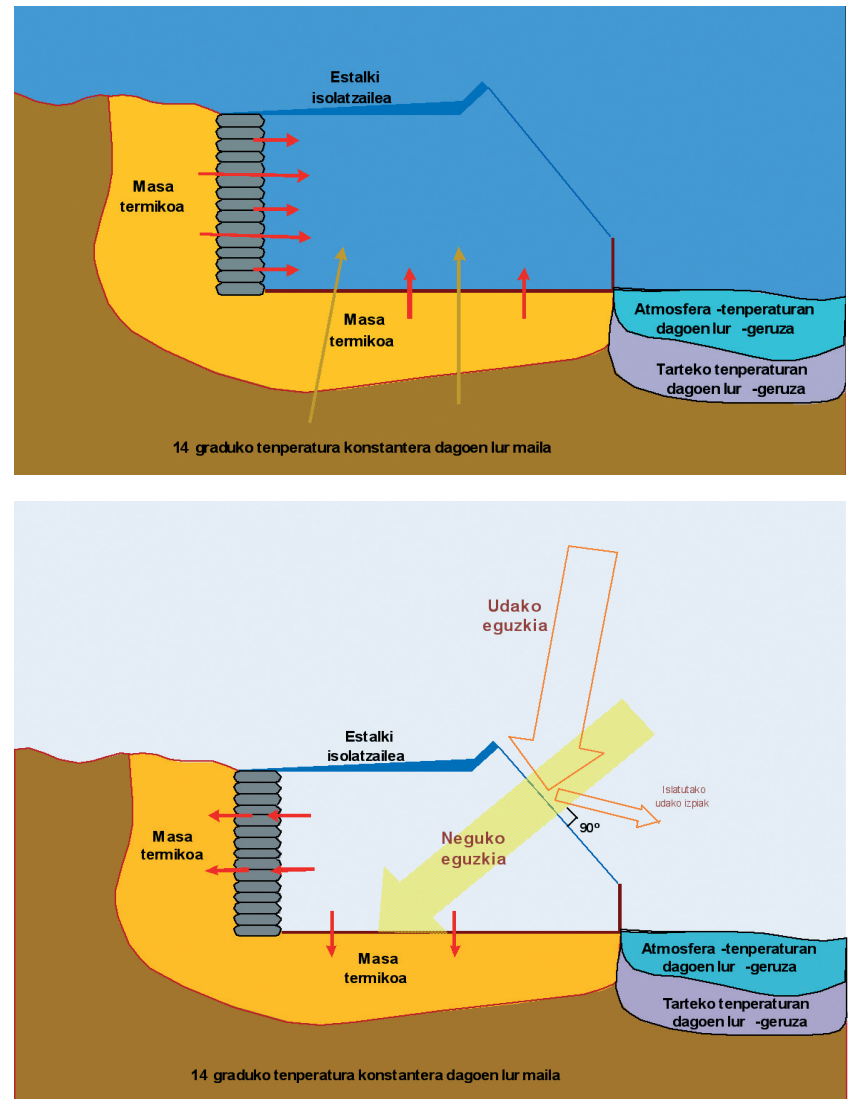

6. irudia. Erthshipen eguzki beroketa pasiboa [26]. 
Gainera, hegoaldean kokatutako leihateei inklinazio egokia ematen bazaie, eguzki-izpiak ahal bezain beste baliatuko dira. Neguan, beroa beharrezkoa gertatzen denean, eguzki-izpien islapena mininizatu egingo da; udan, aldiz, beroa desiragarria ez denean, eguzki-izpien islapena nabarmena izango da (ikusi 6. irudia).

\section{Elektrizitate-hornidurarako sistema}

Earthshipek eurek sortzen dute beharrezko energia elektrikoa; beraz, ez dute sare elektrikoarekin konektatuta egon behar. Beharrezko energia elektrikoa, batez ere, panel fotovoltaiko eta haize-sorgailuei esker lortzen da eta, posible denean, turbina hidraulikoei esker. Lortutako energia baterietan pilatzen da, eta energia antolatzeko moduluak etxe osoan zehar banatuko du energia hori.

\section{Ur-hornidurarako sistema}

Earthshipek euritik eta elurretik eskuratzen dute ura. Ura teilatutik jasotzen da, eta, hodi batzuen bidez, zisterna batzuetatik kanalizatzen da. Zisterna horiek, lurpean jartzen dira, zikinkeriatik eta eguzkitik babesteko. Ondoren, grabitate-indarrari esker, antolatzaile-modulura igaroko da ura, eta, iragazi eta presurizatu ondoren, etxe osoan zehar banatu ahalko da (ikusi 7. irudia).

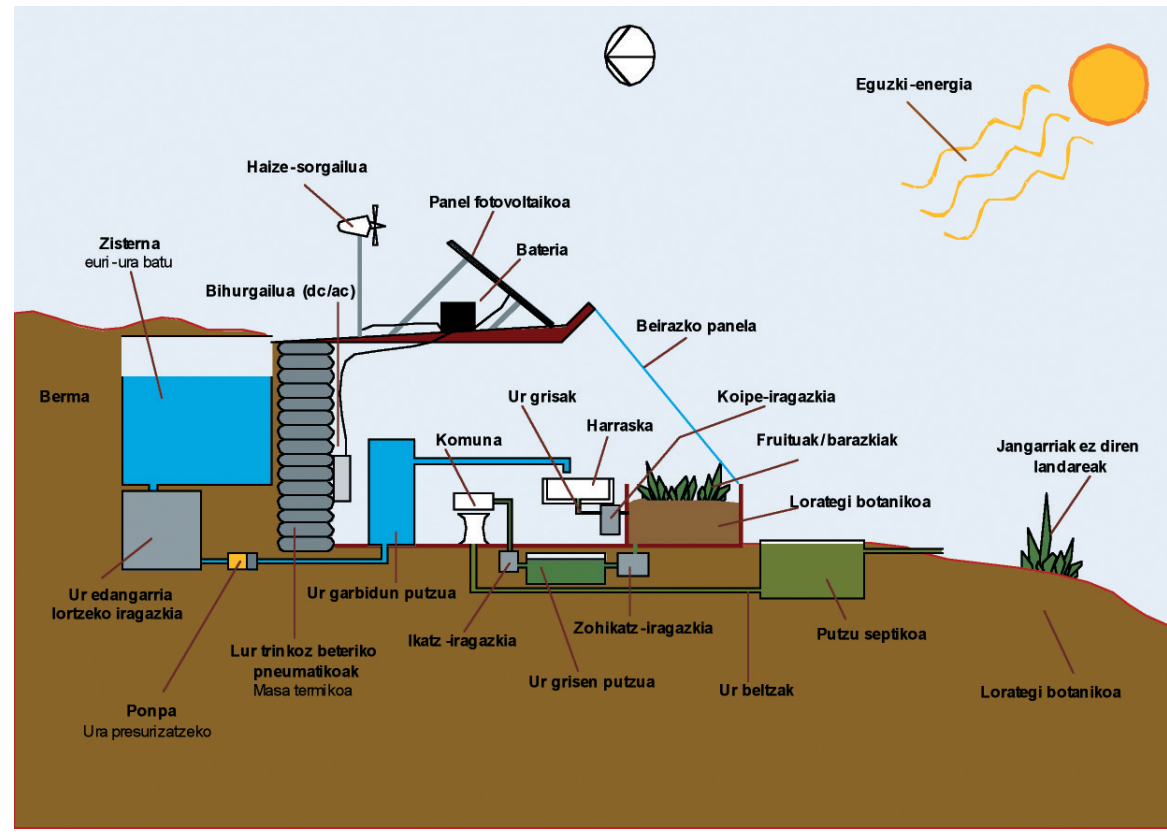

7. irudia. Erthshiparen funtzionamendurako beharrezkoak diren sistemak [27]. 
Earthshipak: Bideragarriak al dira hornidura-sarearekiko konexiorik behar ez duten etxebizitza ekologikoak Euskal Autonomia Erkidegoan?

Ur beroa lortzeko, eguzki-sistema termikoak erabiliko dira. Hala ere, eguzki faltaren ondorioz ura berotu ezin denean, biomasa-galdarak erabiliko dira.

Hondakin-uren kudeaketa-sistema

Earthshipetan hondakin-uren kudeaketarako erabiliko diren sistemei esker, ura lau aldiz erabili ahalko da, eta horrela, ura ahalik eta gehien baliatzea lortuko da.

Lehendabizi, zisternetatik lortutako ur garbia erabiliko da dutxa, konketa, harraska eta abarretan. Ondoren, ur hori koipe-iragazki batzuetatik igaro eta etxe barruko lorategi botanikoak ureztatzeko erabiliko da. Ureztatzeko erabili den ura berriz iragazi eta garbitu ondoren, ez du izango usainik eta komun-ontzieratarako erabili ahalko da, edangarria izango ez bada ere. Azkenik, ur hori putzu septiko batera joango da. Bertan, materia organikoa deskonposatzeko, prozesu anaerobikoa azkarragoa eta eraginkorragoa izango da eguzki-beroaren laguntzari esker. Azken urratsean, lortutako ur hori kanpoko lorategi botanikoa ureztatzeko erabiliko da.

\section{Elikagaien ekoizpen-sistema}

Earthshiparen barruko eta kanpoko lorategi botanikoei esker, barazki, lekale eta fruituak landatu daitezke urte osoan zehar. Etxe barruko lorategietan ia edozer landatu daiteke, baita landare tropikalak; izan ere, alde batetik, lorategian sortzen den klima uniformeki beroa da, eta beste alde batetik, ureztapenerako ur eskuragarri izaten da. Gainera, kanpoko giroarekin hobeto egokitzen diren landareak landatu ahalko dira kanpoaldeko lorategian.

Horrela, etxebizitza horien ezaugarriei esker, ortuariak hazteko baldintza egokiak sortzen dira. Zentzu horretan, familien autohornikuntzarako egoera egokia lortzen da, kanpoaldetik ohiko familia batek beharko duena minimizatuz.

Ondorengo 7. irudian laburbilduko dira earthship baten funtzionamendurako beharrezkoak diren sistemak.

\subsubsection{Earthship-modeloak}

Earthship kontzeptua etengabeko bilakaeran dagoen kontzeptua izaki, hainbat modelo eta diseinu aurkitu daitezke mundu osoan zehar. Honako hauek dira egun ezagutzen diren modeloetariko batzuk: global, vaulted global, simple survival, packaged, tropical eta custom design. Aitzitik, earthship-modelo edo -diseinurik egokiena bilatzerako orduan kontuan izan beharreko hainbat aldagai egongo dira, besteak beste, earthshipa eraikiko den 
inguruneko klima, aurrekontuaren zenbatekoa eta norbanakoen beharrizanak [24].

Hala ere, modelo horien artean bi nabarmentzen dira: global modeloa eta simple survival modeloa [19]. Izan ere, lehenengoa modelorik unibertsalena da; eta bigarrenak aurrekontu minimoa exijitzeaz gain, bere sinpletasuna medio, eraikuntza baimenik behar ez duten eraikin eta funtzioetara bideratu daiteke [24].

\section{Global modeloa}

Earthship-modelorik unibertsalena, beraz, global modeloa da. Modelo hori klima gehienetara egokitu daiteke, eta etxe konbentzionalek izaten dituzten erosotasun guztiak izan ditzake, betiere, earthshipen oinarriak errespetatuz. Gainera, Eraikuntzako Kode Teknikoa bete beharko du, eta eraikuntza berriko etxebizitzek bete beharreko urrats legal guztiak jarraitu beharko ditu.

Kostuari dagokionez, earthship horien kostua etxebizitza konbentzionalen antzekoa izango da. Hala ere, arestian esan bezala, etxebizitza horiek eurek sortuko dute beharrezko bero edo hotza, energia elektrikoa, ura eta janaria.

Simple survival modeloa

Earthship-modelorik merkeena modura ezagutzen da, eta printzipioz, ez du eraikuntza baimenik behar. Earthship horiek oso diseinu sinplea daukatenez, nahiz eta etxebizitza gisa erabili ahalko diren, baimen berezirik behar ez duten funtzioetara bideratu daitezke; esaterako, abereentzako aterpeak eraiki daitezke modelo horrekin.

\section{EARTHSHIPA EUSKAL AUTONOMIA ERKIDEGOAN}

Nahiz eta badiren berrogei urte baino gehiago lehen earthshipa eraiki zenetik, kontzeptu hori oso berria da EAEn (Euskal Autonomia Erkidegoan). Hala ere, badago hasi denik kontzeptu hori garatzen. Baina, betetzen al dira EAEn eraikin edo etxebizitza horien bideragarritasuna posible egiten duten faktoreak?

\subsection{Earthship kontzeptuaren hastapenak Euskal Autonomia Erkidegoan}

Earthship kontzeptua zabaltzeko eta garatzeko asmoz, 2014ko urtarrilean Earthship Euskal Herria taldea sortu zen. Taoseko Earthship Bio- 
Earthshipak: Bideragarriak al dira hornidura-sarearekiko konexiorik behar ez duten etxebizitza ekologikoak Euskal Autonomia Erkidegoan?

tecture Academy izeneko akademian trebatu ondoren, egun, earthship bat eraikitzeko beharrezkoak diren urrats guztietan zerbitzua eskaintzen dute, Earthship Euskal Herriako kideek eraikin horien inguruko informazio eta aholkularitza eskaintzeaz gain: proiektu-fasean, gauzatze-fasean eta mantenu-fasean.

Oraindik EAEn ez da earthship etxebizitza baten proiekturik garatu, baina eman dira dagoeneko lehen urratsak earthshipen oinarriak erabilita. Alde batetik, Otxandioko baserri batean (Txirtxor baserrian) aplikatu dira earthshiparen oinarriak: ipar-mendebaldeko eta ipar-ekialdeko hormak isolatu dira kanpoaldetik, harrizko hormek masa termikoa mantendu dezaten barrualdean; negutegi bat eraiki da hego-ekialdean dagoen atartean, eta bertan lorategi bat egin da latekin; botilak erabiliz horma desberdinak eraiki dira; eta baserriaren kanpoaldean putzu txiki bat egin da errekatik datorren ura batu ahal izateko. Beste alde batetik, simple survival ereduari jarraituz abereentzako aterpe bat eraikitzen ari dira Otxandion.
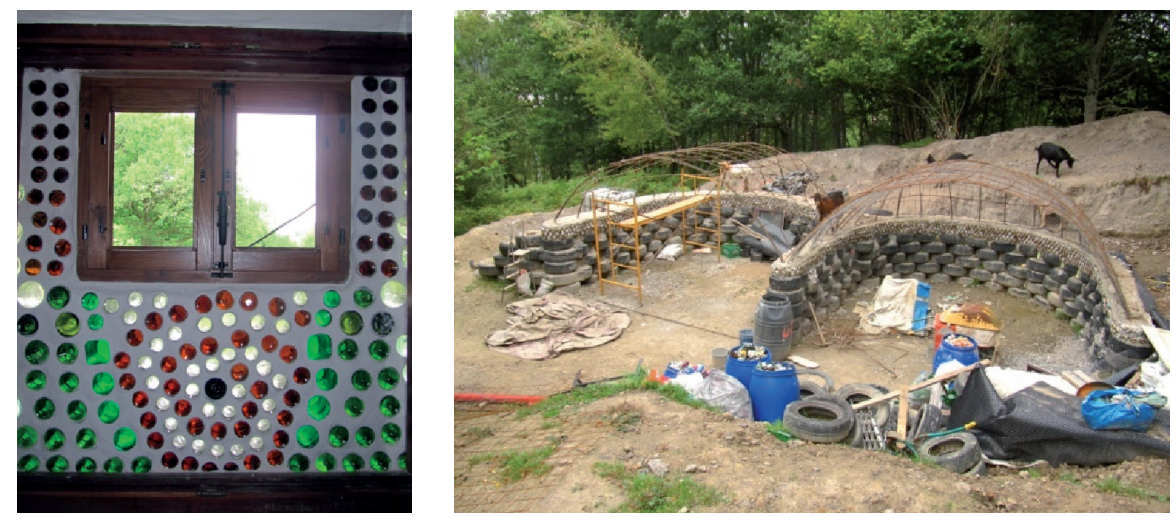

8. irudia. Botilak erabiliz eginiko horma Txirtxor baserrian eta abereentzako aterpearen obra-lanak [19].

\subsection{Earthshipen bideragarritasunari eragiten dioten faktoreen azterketa Euskal Autonomia Erkidegoan}

Lurralde jakin batean earthship baten bideragarritasuna aztertzerako orduan hiru arlotako ezaugarriak aztertu beharko ditugu: klima, legedia eta kostuak. Alegia, eartshipa eraikitzea bideragarria den jakiteko, hurrengo faktoreak aztertu beharko dira: lehenik, lurraldeak duen klimaren ezaugarriak zein tokiko orografia; bigarrenik, lurraldean indarrean dagoen legedia, bereziki, etxebizitza mota hauei erreferentzia egiten dieten atalak; azkenik, mota horretako etxebizitza bat eraikitzeko izan dezakegun kostuaren estimazioa. 
Beraz, ondorengo lerroetan aldagai horiek aztertuko dira EAEren kasurako.

EAEko klima eta beste zenbait ezaugarri

Aurrerago esan den bezala, EAE ez da klima bortitzeko lurraldea (ikusi 1. taula).

1. Taula. Euskal Autonomia Erkidegoko klimatologia [21].

\begin{tabular}{lcc}
\hline \multicolumn{3}{c}{ Euskal Autonomia Erkidegoko klimatologia (2013 urtea) } \\
\hline Urteko & Maximo absolutua & 41,6 \\
tenperatura $\left({ }^{\circ} \mathrm{C}\right)$ & Minimo absolutua & $-7,6$ \\
& Batez bestekoa & 12,7 \\
\hline Urteko batez besteko prezipitazioa $\left(1 / \mathrm{m}^{2}\right)$ & 1.729 \\
\hline Eguneko batez besteko hezetasuna $(\%)$ & 82,80 \\
\hline Eguneko batez besteko irradiazioa $\left(\mathrm{MJ} / \mathrm{m}^{2}\right)$ & 11,37 \\
\hline
\end{tabular}

EAEn tenperaturak nahiko leunak dira, eta prezipitazioak, aldiz, ugariak. Beraz, tenperatura maximo eta minimoak oso bortitzak, eta prezipitazioak oso urriak diren herrialdeetan earthshipak modu arrakastatsuan eraiki badira (Taosen besteak beste), baiezta daiteke EAEn ere horrela izango dela. Alegia, erosotasun termikoa eta ur-horniketa ziurtatuta egongo dira, eskuarki, EAEko earthshipetan. Horren adibide dira EAEko antzerako klima daukan Vermonten (Estatu Batuetako iparraldea) eraikitako earthshipak.

Aldiz, EAE oso hezea eta eguzki-irradiazio gutxikoa da. Hala ere, earthshipak hezetasun handiko eta eguzki gutxiko lurraldeetan ere eraiki dira. Horren adibide dira Eskozia eta Ingalaterra bezalako herrialdeetan eraikitako earthshipak [1]. Hezetasunaren kasuan garrantzitsua izango da lurrun-barrera hermetikoa jartzea, aireztapena egokia izatea eta eguzki izpien sarrera egokia lortzea [28]. Aldiz, eguzki urritasunari dagokionez, urritasun hori konpentsatzeko panel fotovoltaiko kopurua eta mota moldatu beharko dira. Gainera, haize-sorgailuak ere erabil daitezke, eta errekaren bat hurbil izanez gero, turbina hidraulikoak ere erabil daitezke.

Bestalde, EAE lurralde malkartsua da, oro har eta horrek, paisaia-inpaktua murrizten lagunduko du. Earthshipak ezponda edo malda baten hondeaketan kokatuko diren eraikinak izaki, hobeto egokituko dira zonalde malkartsuetara. 
Earthshipak: Bideragarriak al dira hornidura-sarearekiko konexiorik behar ez duten etxebizitza ekologikoak Euskal Autonomia Erkidegoan?

\section{EAEan earthshipen inguruan indarrean dagoen legedia}

Earthshipek, bestelako eraikinen legezko izapide guztiak bete behar dituzte: proiektua, udal-lizentzia eta arkitekto-elkargoaren oniritzia. Gainera, eraikin horiek espainiar Eraikuntzaren Kode Teknikoak jasotzen ez dituenez, arkitektoa da egitura bermatu beharko duena [29]. Bestetik, arautegiak baimentzen du homologatu gabeko materialen erabilera, beti ere, seguruak direla ziurtatzen bada [30].

Hala ere, gerta daiteke proiektuaren onespena lortzeko udaleko teknikarien mesfidantzari aurre egin behar izatea. EAEn earthshipen eraikuntzan aurrekaririk eta tradiziorik ez izatea arazo bihur daiteke, eraikuntza horiek legeztatzeko orduan [30]. Aitzitik, aurreikusten da EAEn lehen earthshiparen legeztatzeak erraztu egingo diela bidea ondorengoei.

Bestalde, 2013ko abuztuaren 30ean argitaratutako EAEko etxebizitzaren lege proposamenak, aintzakotzat hartzen du etxebizitzen arloan iraunkortasuna delako kontzeptua. Gainera, iraunkortasun-printzipioak gauzatzeko bete beharreko eraikuntza-irizpideak eta ekimen batzuk zehazten dira. Ordea, legeproposamenak eraikinek jasangarritasun-printzipioak bete beharko dituztela adierazten duen arren, ez die erreferentzia egiten dagoeneko printzipio horiek betetzen dituzten etxebizitza ezkonbentzionalei. Hala ere, esan bezala, oraindik lege proposamena baino ez da, eta egun, eztabaida-fasean dago [31].

\section{EAEn earthship bat eraikitzearen kostua}

EAEn earthship bat eraikitzearen kostua ( global modeloa) etxebizitza konbentzional bat eraikitzearen antzekoa izango da (1.100 euro metro karratuko ${ }^{2}$ ), edo, kasuan kasu, garestiagoa ere izan daiteke. Alabaina, Earthship Biotecture konpainiak planoak garatu ondoren, kostua \% 40 inguru murriztu ahalko da, earthshipa norberak egitea erabakiz gero [24]. Gainera, nahiz eta eraikuntza ezaupide urriak izan, kasu honetan eraikuntza teknikak oso sinpleak dira eta beraz, autoeraikuntza guztiz posible izango da.

Ordea, arazo bat izan daiteke finantziazioa lortu beharra. Izan ere, ohiko etxebizitzetarako mailegua lortzea zaila den garaian, nekez lortuko da earthship baterako.

\section{ONDORIAK}

Orain dela gutxira arte, gure inguruko etxebizitzak ingurunea errespetatuz eraikitzen ziren. Euskal baserriak, oro har, eguzkiaren orientazioa, aire-

\footnotetext{
2 Familia bakarreko etxebizitza jakin batentzako ekonomia eta finantza bideragarritasun-azterketaren arabera, higiezin produktu jakin baten eraikitze kostua 1.100 eurotakoa da.
} 
korronteak, eta beroa sortu edo mantentzeko banaketa kontuan izanda eraikitzen ziren eta zer esanik ez, lekuan lekuko materialez baliatuz. Baina hori guztia alde batera utzi eta eraikuntzak beste norabide bat hartu zuen [30]. Azken urteotan, etxebizitzak eraikitzeko orduan kontuan izan beharreko parametroak zeharo desberdinak izan dira. Jasangarritasun-irizpideetatik oso urrun dago egungo eraikuntza EAEn, baina horrek ez du esan nahi etorkizunean jarrera honek bere horretan jarraitu behar duenik.

Bioeraikuntzaren bidez, gaur egungo eraikuntza-eredua aldatu eta ingurumenaren eta bertan bizi diren gizakien arteko oreka aurkitu nahi dute. Horretarako, beharrezkoa izango da bai energia-eraginkortasuneko eraikinak izatea, bai eta eraikitzeko orduan erabilitako materialek ingurumenari ahalik eta gutxien eragitea.

Azken urteotan, bioeraikuntzaren oinarriak aplikatuz hainbat etxebizitza mota eraiki badira ere (egurrezko etxebizitzak, lastozkoak, lurrezkoak eta abar), esan daiteke haien artean earthshipak izan direla eraikuntza konbentzionalaren eredua guztiz eraldatu dutenak.

Earthshipak material birziklatuez eta, neurri handi batean, material naturalez eraikitako etxebizitza ekologiko eta autonomoak dira. Material birziklatuak (pneumatikoak, aluminiozko freskagarri-latak eta kristalezko edo plastikozko botilak, batez ere) eta material naturalak (lurra, batez ere) dira earthshipak eraikitzeko funtsezko materialak. Bestalde, earthshipak ez dira hornidura-sareekin konektatzen, pasiboki berotzen eta hozten baitira; behar duten elektrizitatea sortzen dute eta behar duten ura batzen dute; horretaz gain, hondakin-urak tratatzen dituzte eta janaria ekoizten dute.

Lehenengo earthshipa Taosen (Mexiko Berrian) orain dela berrogei bat urte eraiki zen eta gaur egun mundu osoan zehar 3.000 baino gehiago daude, baina EAEn guztiz ezezaguna da eraikuntza mota hori. Hala ere, tokian tokiko berezitasunak kontuan izanda, EAE lurralde egokia da horrelako eraikuntzak egiteko. Klimatologia aldetik lurralde egokia da, eta eraikuntza metodo modura autoeraikuntza aukeratuz gero, etxebizitza konbentzional bat egitea baino merkeagoa izan liteke. Legediari dagokionez, aztertutakoaren arabera ez litzateke zertan eragozpenik egon, baina EAEn earthshipetan aurrekaririk eta tradiziorik ez izatea oztopo bihur daiteke eraikuntza horiek legeztatzeko orduan.

Edonola, garaia iritsi da EAEko erakundeek eraikuntzaren egungo egoeraz jabetu eta etorkizunerako benetan zer nahi den berriz zehazteko; gainera, badirudi, Europako zuzentarauak medio (2010/31/EU), ondorengo urteetan emango diren urratsak eraikinen energia-eraginkortasuna lortze aldera bideratuko direla. Alabaina, berez, jasangarritasuna ez dago ziurtatuta. Eman beharreko urratsek haragokoak izan beharko dute, eta gauzak horrela, earthshipenak bezalako esperientziak oso lagungarri gerta daitezke. Hala, earthshipen oinarriak lagungarriak izan daitezke, ez bakarrik eraikiko 
Earthshipak: Bideragarriak al dira hornidura-sarearekiko konexiorik behar ez duten etxebizitza ekologikoak Euskal Autonomia Erkidegoan?

diren etxebizitza berrietan, baita dagoeneko badauden etxebizitzek energia aurreztu dezaten, ekologikoagoak izan daitezen, toxikotasun gutxiago izan dezaten eta abar.

\section{ESKER ONAK}

Egileok gure esker ona adierazi nahi diegu Earthship Euskal Herria ${ }^{3}$ taldeko kideei, hain atsegina egin zaigun ikerlan honetan irakatsi diguten guztiagatik eta gureganako izan duten adeitasunagatik.

Aldi berean, eskerrak luzatu nahi dizkiogu Euskal Filologia Saileko Jose Ramon Etxebarriari, testuaren euskara txukuntzen laguntzeagatik eta berarekin ikasi dugun guztiagatik.

\section{BIBLIOGRAFIA}

[1] IP, K. eta MILLER, A. 2009. «Thermal behaviour of an earth-sheltered autonomous building - The Brighton Earthship». Renewable Energy, 34, 20372043.

[2] CIBSE. 2004. TM34 Climatic change with weather change scenario. CIBSE, London

[3] FERNÁNDEZ, I. 2012. EECN: Más allá de la eficiencia energética. Eficiencia ambiental, permacultura aplicada y materiales nobles. I Congreso EECN, Madrid.

[4] ECOHABITAR. 2014. Un hábitat saludable y ecológico. Eskuragarri: http:// www.ecohabitar.org [2014, 10/27].

[5] EUROPEAN PARLIAMENT. 2003. Directive 2002/91/EC of the European Parliament and of the Council of 16 December 2002 on the energy performance of buildings. Official Journal of the European Communities, published on January 4, 2003 (L 1/65).

[6] EUROPEAN PARLIAMENT. 2010. Directive 2010/31/EU of the European Parliament and of the Council of 19 May 2010 on the energy performance of buildings (recast). Official Journal of the European Communities, published on June 18, 2010 (L 153/13).

[7] REAL DECRETO 235/2013, de 5 de abril, por el que se aprueba el procedimiento básico para la certificación de la eficiencia energética de los edificios. BOEn argitaratua, 89, 2013ko apirilak 13.

[8] CURIA. 2014. Sentencia del tribunal de justicia (Sala Décima) de 16 de enero de 2014 sobre Incumplimiento de Estado Directiva 2002/91/CE. Eskuragarri: http://curia.europa.eu/juris/document/document.jsf?text=\&docid=

\footnotetext{
${ }^{3}$ http://earthshipstxirtxor.jimdo.com
} 
146442\&pageIndex $=0 \&$ doclang $=E S \&$ mode $=1$ st $\&$ dir $=\& o c c=$ first $\&$ part $=1 \& c$ id $=40518$ [2014, 10/29]

[9] REYNOLDS, M.E. 1990. Earthship. How to build your own, vol. 1. Solar Survival Press, Taos, New Mexico.

[10] REYNOLDS, M.E. 1991. Earthship. How to build your own, vol. 2. Solar Survival Press, Taos, New Mexico.

[11] REYNOLDS, M.E. 1993. Earthship. How to build your own, vol. 3. Solar Survival Press, Taos, New Mexico.

[12] AUDENAERT, A.; DE CLEYN, S.H. eta VANKERCKHOVE, B. 2008. «Economic analysis of passive houses and low-energy houses compared with standard houses». Energy Policy, 36, 47-55.

[13] SARTORI, I. eta HESTNES, A.G. 2007. «Energy use in the life cycle of conventional and low-energy buildings: A review article». Energy and Buildings, 39, 249-257.

[14] JOHN, G.; CLEMENTS-CROOME, D. eta JERONIMIDIS, G. 2005. «Sustainable building solutions: A review of lessons from the natural world». Building and Environment, 40,319-328.

[15] KUIL, E. 2012. The sustainability of conventional houses, passive houses and earthships, based on legislation, environmental impact energy and operating energy. University of Groningen.

[16] EUROPEAN COMMISSION. 2009. Low energy buildings in Europe: Current state of play, definitions and best practice.

[17] REAL DECRETO 314/2006, de 17 de marzo, por el que se aprueba el Código Técnico de la Edificación. BOEn argitaratua, 74, 2006ko martxoak 28.

[18] MARTÍNEZ DE ALEGRÍA, I.; VICENTE-MOLINA, M.A.; ÁLVAREZ, I. eta ZARRABEITIA, E. 2014. European Union Policy against the climate change: the case of the Spanish Strategy for the implementation of the objectives regarding the Nearly Zero-Energy Buildings (NZEB). 11th International Conference Developments in Economic Theory and Policy, Bilbao.

[19] EARTHSHIP EUSKAL HERRIA. 2014. Earthship Euskal Herria, aske bizitzeko diseinatutako etxea. Eskuragarri: http://earthshipstxirtxor.jimdo.com [2014, 10/24].

[20] HEWITT, M. eta TELFER, K. 2007. Earthships: Building a Zero Carbon Future for Homes. Bracknell, IHE BRE Press.

[21] EUSTAT. 2014. Euskal Estatistiko Erakundea. Eskuragarri: www.eustat.es [2014, 10/30].

[22] SEYFANG, G. 2009. The new economics of sustainable consumption. Palgrave Macmillan.

[23] EEBU (2013). European Earthship Builders United. Eskuragarri: http:// eebu .earthshipeurope.org/ [2014, 11/03].

[24] EARTHSHIP BIOTECTURE. 2014. Earthship Biotecture. Eskuragarri: http://earthship.com [2014, 10/24].

[25] DI RUSCIO, N. 2014. Los neumáticos son peligrosos en las pilas, no en las NavesTierra.Eskuragarri: http://nicolasdiruscio.redirectme.net/archivos/ 
Earthshipak: Bideragarriak al dira hornidura-sarearekiko konexiorik behar ez duten etxebizitza ekologikoak Euskal Autonomia Erkidegoan?

Libros/NaveTierra\%20-\%20Emision\%20de\%20gases\%20neumaticos.pdf [2014, 11/03].

[26] ECOCASAS. 2014. Earthship, una nave para nuestro paso por la tierra. Eskuragarri: http://ecocosas.com/arq/earthship/ [2014, 10/24].

[27] OFF-GRIDDING. 2014. Earthships. Eskuragarri: http://www.offgridding. com/earthships.html [2014, 10/24].

[28] EARTHSHIP NEW ZEALAND. 2014. Earthship New Zealand. Eskuragarri: http://earthship.co.nz [2014, 10/30].

[29] DOMOTERRA. 2014. Domoterra, casas de tierra. Eskuragarri: http://www. domoterra.es/ [2014, 10/30].

[30] RTVE. 2014. El escarabajo verde. Esta casa es un tesoro. Eskuragarri: http://www.rtve.es/alacarta/videos/el-escarabajo-verde/escarabajo-verdeesta-casa-tesoro/2814575/ [2014, 11/03].

[31] LEGE PROPOSAMENA (10/09.02.02.0005), Etxebizitzarena, Eusko Legebiltzarreko Aldizkari Ofizialean argitaratua 2013ko abuztuaren 30ean. 